\title{
TUBERCULOUS PLEURAL EFFUSION IN THE PREVIOUSLY HEALTHY MAN - CASE REPORT AND REVIEW OF THE LITERATURE
}

\author{
Lazovic Biljana, ${ }^{1}$ Blazic Ivana, ${ }^{1}$ Detanac Dzemail, ${ }^{2}$ Milic Rade, ${ }^{3}$ \\ Sarac Sanja, ${ }^{3}$ Detanac Dzenana, ${ }^{2}$ Zugic Vladimir ${ }^{4}$ \\ 'University clinical center "Zemun”, Belgrade, Serbia \\ ${ }^{2}$ General Hospital Novi Pazar, Serbia \\ ${ }^{3}$ Military Medical Academy, Clinic for pulmonology, Belgrade, Serbia \\ ${ }^{4}$ Clinic for lung diseases, Clinical center of Serbia, Belgrade, Serbia, University of Belgrade, Serbia
}

Primljen/Received 26. 05. 2019. god.

Prihvaćen/Accepted 17. 06. 2019. god.

Abstract: Introduction: Although pleural effusion is a common clinical manifestation, the differential diagnosis of the cause of the pleural effusion is often challenging, especially in the early differentiation of tuberculous pleurisy (TP) from other pleural effusion.

Case report: We present a previously healthy man who had no contagious or TB contact but developed massive tuberculous pleural effusion which eventually was unexpected tuberculous. He started with therapy per protocol and feeling well. The purpose of this case and review of literature was to remind the physicians that tuberculosis is not a sickening illness, but on the contrary, it is in the expansion.

Discussion: When a patient presents with new pleural effusion, the diagnosis of tuberculous pleuritis should be considered. The patient is at great risk for developing pulmonary or extra pulmonary $\mathrm{TB}$ if the diagnosis is not made properly. Between $3 \%$ and $25 \%$ of patients with TB will have TB pleuritic or more in immunocompromised patients. The treatment for TB pleuritis is the same as that for pulmonary TB.

Conclusion: The gold standard for the diagnosis of tuberculous pleural effusion remains the detection of Mycobacterium tuberculosis in pleural fluid, or pleural biopsy specimens, either by microscopy and/or culture, or the histological demonstration of caseating granulomas in the pleura along with acid fast bacilli.

Key words: effusion, pleuritic pain, pleurisy, pleural biopsy, TBC, treatment.

\section{INTRODUCTION}

Tuberculosis accounts for millions of active disease cases and deaths in both developed and developing countries (1). The proportion of patients with tubercu- losis who have pleural effusions has varied markedly from population to population $(1,2)$. Tuberculous pleural effusion occurs in approximately $5 \%$ of patients with Mycobacterium tuberculosis (TB) infection and accounts for $4 \%$ of all TB cases in the United States (2). Diagnosis is challenging, with $48-96 \%$ of tuberculous pleural effusions negative by sputum acid-fast bacilli (AFB) stain and culture $(3,4)$. Thoracentesis is frequently performed and shows an exudative, lymphocytic pleural effusion in more than $90 \%$ of cases but direct examination reveals acid-fast bacilli (AFB) in less than $10 \%$ of cases $(5,6)$. As AFB stain and cultures are often negative and biomarkers cannot guide therapy, more invasive diagnostic measures are usually required. The following case illustrates the clinical presentation and diagnostic approach in anatypical caseof suspected tuberculous pleural effusion, which presented typically eventuallyin a previouslyhealthy man, as well as review of literature.

\section{CASE REPORT}

A male temporary resident of Russian descent, 51 years of age, was referred by a general practitioner (GP) to our hospital because of routinely annually done chest $\mathrm{x}$ ray which showed left sided pleural effusion for further diagnostic. The patient reported that he is mechanical engineer who work in Serbia for 5 years in comfort surroundings. He had not traveled in the past few years.He observed that he had weight lossof 7 kilograms in last 6 months, apart from good appetite, but no shortness of breath at rest, chest pain, fevers, or sick contacts. He had never smoked. He had no infectious contacts or a history of tuberculosis (TB) or immuno- 


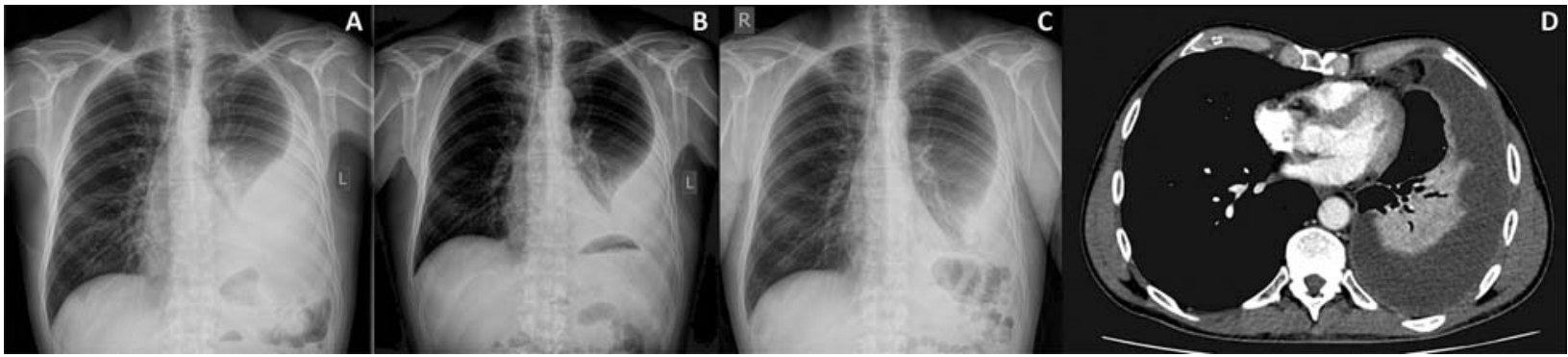

Figure 1. A. B. C. Series of chest X rays showing left plural effusion decreasing under the treatment. $D$. Arterial phase of chest CT showing large pleural effusion on the left side with partial consolidation of the left lover lobe due to inflammatory changes with negative bronchogram sign

suppression. One week prior to presentation, he was empirically treated for pneumonia with levofloxacin without improvement.

On admission the patient was afebrile, with normal blood pressure, $120 / 80 \mathrm{mmHg}$, a heart rate of 110 beats $/ \mathrm{min}$, and $\mathrm{S}_{\mathrm{pO} 2}$ of $96 \%$ while breathing room air. Cardiac sounds were clear. Physical examination revealed dullness to percussion and decreased breath sounds throughout his lefthemithorax, with normal lung sounds on the right. She had no abdominal hepatosplenomegaly or edema of either lower limb. His white blood cell count was $12 \times 10 \%$ Lwith $73 \%$ neutrophils and $14 \%$ lymphocytes, and platelets $460 \times 10^{3}$ cells $/ \mathrm{ml}$. Basic chemistry was normal, exceptC-reactive protein of $49 \mathrm{mg} / \mathrm{L}$. A repeated chest radiograph (Figure 1A) revealed a large left pleural effusion ant it regression after thoracentesis (Figure 1 B, C). Chest computed tomographyshowed large pleural effusion on the left side with inflammatory changes in left lower lobe (Figure 1 D). Human immunodeficiency virus (HIV) test was negative. Expectorated sputum revealed 3 negative stains and cultures for acid-fast - bacillus (AFB). The QuantiFERON-TB Gold (QFT)test was indeterminate. We have done three thoracentesis. Pleural fluid was an exudate with lymphocytic predominance in $90 \%$ of cases.A percutaneous, closed pleural biopsy was performed, using an Abrams needle, yielding 6 pieces of pleural tissue that revealed granulomatous pleuritis with focal necrosis, positive by AFB stain.

The patient was started on an anti-tuberculosis regimen (isoniazid (INH) $300 \mathrm{mg}$, ethambutol (EMB) 800 $\mathrm{mg}$, rifampin (RIF) $450 \mathrm{mg}$ and pyrazinamide (PZA) $1000 \mathrm{mg}$ ) for two months and tolerate well on first control examination. The next phase of the treatment should be INH and rifampin for 4 months. Directly observed therapy (DOT) is recommended. It is also possible to use 9-month therapy of INH and rifampin if the organisms are fully susceptible to the drug (7).

\section{DISCUSSION}

Tuberculous pleuritis usually presents as an acute or subacute illness. Symptoms are present for less than
1 week in $35 \%$ of patients and present for less than 1 month in $71 \%$ (7). The most frequent symptoms are cough $(\sim 70 \%)$, which is usually non-productive, and chest pain ( $70 \%)$, which is usually pleuritic (8). Most patients are febrile, but approximately $15 \%$ will be afebrile $(7,8)$. They may also be dyspneic if the effusion is large. If the presentation is less acute, mild chest pain may occur with at most a low-grade fever, non-productive cough, weight loss, and malaise (9). Our patient had none of symptoms mentioned above, except weight loss, to whom he did not attribute significance due to irregular meals. He had no contagious contact.

Tuberculous pleural effusion (TPE) results from Mycobacterium tuberculosis infection of the pleura and is characterized by an intense chronic accumulation of fluid and inflammatory cells in pleural space (10). TPE is the second most common form of extrapulmonary tuberculosis and a common cause of pleural effusions in endemic tuberculosis areas. TPE is usually unilateral and can be of any size. In the studies of large number population, pleural fluid occurred only on the left side in $127(38.1 \%)$, only on the right in 161 (48.4\%), and both sides were affected in 45 (13.5\%). In either unilateral or bilateral effusion, the percentages of small, moderate, and large size of pleural effusions were $20.4 \%, 19.2 \%$, and $60.4 \%$, respectively $(2,8)$. Approximately $20 \%$ of patients with TPE have coexisting parenchymal disease on chest radiograph. However, computed tomography scanning offers a more sensitive method and can demonstrate parenchymal disease in $40-85 \%$ of cases (11).

TPE predominates in men, with an overall male-to-female ratio of $2: 1(4,12)$. In an epidemiological analysis from the United States, TPE occurs significantly more often than pulmonary tuberculosis among persons $>65$ years old, and the mean age of patients with TPE is 49 years: about $50 \%$ were younger than 45 years and $30 \%$ were over 65 years of age. In contrast, TPE affects mainly younger individuals (mean age $=$ 34 years) in higher tuberculosis burden areas, where primary infection accounts for a large percentage of patients with TPE $(2,13)$. Immunocompromised pati- 
ents are more likely to develop TB than non-immunocompromised patients. Because TB pleuritis is thought to be due to delayed hypersensitivity, one might hypothesize that the percentage of immunocompromised hosts with TB with pleural effusions would be lower than in immunocompetent hosts, which is not always a case $(14,15)$. The incidence of tuberculosis in Serbia shows a trend of swelling and it is estimated that premature data from the Institute of Public Health from 2018 is $10,52 \%$ of which $89 \%$ are pulmonary forms of tuberculosis (16).

The best diagnostic approach to suspected tuberculous pleuritis is debated. The yield of pleural fluid smears is $10 \%$ and of pleural fluid cultures is $25-85 \%$ $(4,17)$. Pleural biopsy histopathology of granulomas or $(+)$ culture has diagnostic yields ranging from 55 to 93\%. Evaluation for TB with thoracentesis plus closed pleural biopsy has a 95\% sensitivity, which is roughly on par with thoracoscopy. Diagnostic modalities with highest yield are slow to show results making acute workup difficult $(4,17)$.

The American Thoracic Society recommends a 6-month regimen for treatment of pleural TB consisting of a 2-month period of Isoniazid (INH), Rifampin (RIF), Ethambutol (EMB) and Pyrazinamide (PZA) and followed by INH and RIF daily for 4 months (17). Corticosteroids have not reduced residual pleural thickening and are not recommended $(17,18,19)$. Therapeutic thoracentesis is not discussed in the guidelines and is controversial, however it is usually performed if a patient is more than mildly symptomatic (17). Significantly less residual pleural thickening and accelerated recovery of pulmonary function has been seen in patients who received therapeutic thoracentesis for TB associated effusions $(19,20)$. However, other studies have concluded that residual pleural thickening is not influenced by this intervention $(18,19,20)$. Other drawbacks to thoracentesis include risk of transmission to health providers, bleeding, and pulmonary injury. Anyway, it's still a subject of study and further analysis perhaps would show the real path.

\section{CONCLUSION}

The diagnosis of TB pleuritis should be considered when a patient presents with new pleural effusion. The gold standard for the diagnosis of tuberculous pleural effusion remains the detection of Mycobacterium tuberculosis in pleural fluid, or pleural biopsy specimens, either by microscopy and/or culture, or the histological demonstration of caseating granulomas in the pleura along with acid fast bacilli. If the diagnosis is not made, the patient is at risk for developing pulmonary or extrapulmonary tuberculosis. The recommended treatment for TB effusion is a regimen with Isoniazid, Rifampin, Ethambutol and Pyrazinamide for two months followed by four months of two drugs, isoniazid and rifampin.
Abbreviations
TP — tuberculous pleurisy
TB - Mycobacterium tuberculosis
AFB - acid-fast bacilli
TPE - Tuberculous pleural effusion

\section{Acknowledgment: None}

Conflict of Interests: The authors declare that there are no conflicts of interest related to this article.

Funding: This research did not receive any specific grant from funding agencies in the public, commercial, or not-for-profit sectors.

\section{Licensing}

This work is licensed under a Creative Commons Attribution 4.0 International (CC BY 4.0) License.

\title{
Sažetak
}

\section{TUBERKULOZNI PLEURALNI IZLIV KOD PRETHODNO ZDRAVOG PACIJENTA - PRIKAZ SLUČAJA I PREGLED LITERATURE}

\author{
Lazovic Biljana, ${ }^{1}$ Blazic Ivana, ${ }^{1}$ Detanac Dzemail, ${ }^{2}$ Milic Rade, ${ }^{3}$ \\ Sarac Sanja, Detanac Dzenana, ${ }^{3}$ Zugic Vladimir ${ }^{4}$ \\ ${ }^{1}$ University clinical center „Zemun“, Belgrade, Serbia \\ ${ }^{2}$ General Hospital Novi Pazar, Serbia \\ ${ }^{3}$ Military Medical Academy, Clinic for pulmonology, Belgrade, Serbia \\ ${ }^{4}$ Clinic for lung diseases, Clinical center of Serbia, Belgrade, Serbia, University of Belgrade, Serbia
}

Uvod: Iako je pleuralni izliv uobičajena klinička manifestacija, diferencijalna dijagnostika uzroka ovog izliva je često izazovna, posebno u ranoj diferencijaciji tuberkuloznog pleuritisa od drugog pleuralnog izliva.
Prikaz slučaja: Predstavljamo ranije zdravog muškarca koji nije imao kontakta sa tuberkuloznom infekcijom, ali je razvio masivni tuberkulozni pleuralni izliv koji je na kraju bio neočekivano tuberkulozan. Počeo je sa tera- 
pijom po protokolu i osećao se dobro. Svrha ovog slučaja i pregled literature je bila da se lekari podsete da tuberkuloza nije bolest u nestajanju, već naprotiv - da je u ekspanziji.

Diskusija: Kada pacijent ima novi pleuralni izliv, treba razmotriti dijagnozu tuberkuloznog pleuritisa. Pacijent je pod velikim rizikom za razvoj pulmonalne ili ekstra pulmonalne tuberkuloze ukoliko se dijagnoza ne postavi pravilno. Između 3 i 25\% pacijenata sa tuberkulozom će imati tuberkulozni pleuritis, a ovaj procenat je veći kod pacijenata sa oslabljenim imunite-

\section{REFERENCES}

1. Global tuberculosis report 2015. Geneva: World Health Organization, 2015.

2. Baumann MH, Nolan R, Petrini M, Lee YC, Light RW, Schneider E. Pleural tuberculosis in the United States: incidence and drug resistance. Chest 2007; 131(4): 1125-32.

3. Light RW. Update on tuberculous pleural effusion. Respirology. 2010; 15(3): 451-8.

4. Light RW. Pleural diseases. 6th edition. Philadelphia: Lippincott Williams \& Wilkins; 2013.

5. Chadha SL, Bhagi RP. Treatment outcome in tuberculosis patients placed under directly observed treatment short course (dots) -a cohort study. Ind J Tub. 2000; 47(3): 155-8.

6. Udwadia ZF, Sen T. Pleural tuberculosis: An update. Curr Opin Pulm Med. 2010; 16(4): 399-406.

7. Dutt AK, Moers D, Stead WW. Tuberculous pleural effusion: 6-month therapy with isoniazid and rifampin. Am Rev Respir Dis. 1992; 145(6): 1429-32.

8. Valdes L, Alvarez D, San Jose E, Penela P, Valle JM, García-Pazos JM et al. Tuberculous pleurisy: a study of 254 patients. Arch Intern Med. 1998; 158(18): 2017-21.

9. Seiscento M, Vargas FS, Bombarda S, Sales RK, Terra RM, Uezumi K et al. Pulmonary involvement in pleural tuberculosis: How often does it mean disease activity? Respir Med. 2011; 105(7): 1079-83.

10. Porcel JM, Vives M. Etiology and pleural fluid characteristics of large and massive pleural effusions. Chest. 2003; 124(3): 978-83.

11. Qiu L, Teeter LD, Liu Z, Ma X, Musser JM, Graviss EA.. Diagnostic associations between pleural and pulmonary tuberculosis. J Infect. 2006; 53(6): 377-86.

12. Ong A, Creasman J, Hopewell PC, Gonzalez LC, Wong M, Jasmer RM et al. A molecular epidemiological assess- tom. Lećenje tuberkuloznog pleuritisa je isto kao i za plućnu tuberkulozu.

Zaključak: Zlatni standard za dijagnostikovanje tuberkuloznog pleuralnog izliva ostaje u detekciji Mycobacterium tuberculosis u pleuralnoj tečnosti, ili uzorcima pleurelne biopsije, bilo mikroskopijom ili kulturom, kao i histološkom verifikacijom kazeoznog granuloma u pleuru zajedno sa kiselim bacilima.

Ključne reči: izliv, pleuritski bol, upala pluća, pleuralna biopsija, tuberkuloza, lečenje.

ment of extrapulmonary tuberculosis in San Francisco. Clin Infect Dis. 2004; 38(1): 25-31.

13. Torgersen J, Dorman SE, Baruch N, Hooper N, Cronin W.. Molecular epidemiology of pleural and other extrapulmonary tuberculosis: a Maryland state review. Clin Infect Dis. 2006; 42(10): 1375-82.

14. Aljohaney A, Amjadi K, Alvarez GG. A systematic review of the epidemiology, immunopathogenesis, diagnosis, and treatment of Pleural TB in HIV infected patients. Clin Dev Immunol. 2012: 842045 .

15. Saks AM, Posner R. Tuberculosis in HIV positive patients in South Africa: a comparative radiological stud with HIV negative patients. ClinRadiol. 1992; 46(6): 387-90.

16. Institut za javno zdravlje, BATUT. Izveštaj o zaraznim bolestima u Republici Srbiji, 2018.god.Available on: www. batut.org.rs/ download /izvestaji/ Godisnji\%20 izvestaj\%20 zarazne\%20bolesti\%202017.pdf.

17. Porcel JM. Tuberculous pleural effusion. Lung. 2009; 187(5): 263-70.

18. Payam N, Dorman SE, Alipanah N, Barry PM, Brozek JL, Cattamanchi A, et al. Official American Thoracic Society/ Centers for Disease Control and Prevention/Infectious Diseases Society of America Clinical Practice Guidelines: Treatment of Drug-Susceptible Tuberculosis. 2016; 63: 853-67.

19. Schunemann HJ, Jaeschke R, Cook DJ, Bria WF, El-Solh AA, Ernst A et al. An official ATS statement: grading the quality of evidence and strength of recommendations in ATS guidelines and recommendations. Am J RespirCrit Care Med. 2006; 174(5): 605-14.

20. Guyatt GH, Oxman AD, Vist GE, Kunz R, Falck-Ytter Y, Alonso-Coello P et al. GRADE: an emerging consensus on rating quality of evidence and strength of recommendations. BMJ. 2008; 336(7650): 924-6.

\section{Correspondence to/Autor za korespondenciju}

Biljana Lazović

University Clinical Center „Zemun“, Belgrade, Serbia

Vukova 9, Zemun, 11080 Belgrade

Self phone +38162212040

Fax +3812141569

lazovic.biljana@gmail.com 